\title{
MENGENAL MAKROALGA Turbinaria DAN PEMANFAATANNYA
}

\section{Oleh}

\section{Tri Handayani ${ }^{1)}$}

\section{ABSTRACT}

KNOWING MACROALGAE Turbinaria AND THEIR USAGES. Turbinaria is a member of brown macroalgae that can be found in almost all Indonesian waters. Turbinaria is often regarded as Sargassum because they have a similar morphology and both belong to the Family Sargassaceae. There are 35 species of Turbinaria in the world and 11 of which can be found in Indonesia. Turbinaria conoides, T. decurrens and $\mathrm{T}$. ornata are the most common ones in Indonesian waters. Turbinaria grows on rocky intertidal coastlines, tidepools and reef flats. The life cycle of Turbinaria occurs through alternations between sexual and asexual. Their biphasic life cycle contains gametophytes and sprorophytes. In their sexual reproduction, sporophytes resulted from the germination of zygotes formed by fusion (fertilization) of male and female gametes. Asexual spores develop from both sporophytes and gametophytes. Turbinaria was commonly used as a source of alginate, fucoidan and other bioactive polysaccharides (antioxidant, anticancer, antibacterial, anticoagulant, antiploriferative and antivirus activities).

\section{PENDAHULUAN}

Makroalga atau yang sebagian disebut sebagai rumput laut (seaweed) merupakan tumbuhan yang hidup di laut. Tumbuhan ini termasuk dalam golongan tumbuhan tingkat rendah, karena tidak memiliki akar, batang dan daun yang sesungguhnya (Atmadja et al., 1996). Makroalga ini berbeda dengan tumbuhan Angiospermae (tumbuhan tingkat tinggi) yang hidup di laut yang biasa disebut dengan lamun (seagrass). Makroalga tersebar hampir di seluruh perairan Indonesia, dengan salah satu makroalga yang umum ditemukan (common species) adalah dari Marga Turbinaria.

Turbinaria merupakan salah satu marga yang masuk dalam kelompok makroalga coklat (Ochrophyta). Turbinaria mempunyai peranan yang sangat penting di dunia industri sebagai bahan baku alginat. Meskipun demikian, makroalga ini tidak termasuk dalam kategori komoditas unggulan rumput laut oleh Kementerian Kelautan dan Perikanan seperti Eucheuma, Kappaphycus, Gracilaria dan Gelidium (KKP, 2016).

Marga Turbinaria sering kali dianggap sebagai Sargassum karena morfologinya yang mirip. Hal ini dikarenakan ketidaktahuan perbedaan antara Turbinaria dengan Sargassum. Kesalahan dalam pengenalan Turbinaria sebagai Sargassum atau makroalga coklat lainnya tentu memberikan dampak yang cukup besar seperti: (1) untuk

\footnotetext{
$\overline{{ }^{1)} \text { Pusat Penelitian Oseanografi - LIPI }}$
} 
standar pasokan industri pengolahan alginat umumnya membutuhkan makroalga coklat yang berasal dari satu spesies (Rasyid, 2003), (2) Turbinaria merupakan salah satu makroalga coklat yang memiliki polisakarida bioaktif yang dimanfaatkan untuk industri farmasi sehingga pemberian nama spesies yang benar menjadi suatu keharusan karena setiap spesies makroalga memiliki kandungan metabolit yang berbeda (Handayani, 2014).

Tulisan ini akan mengulas tentang sistematika, diversitas, habitat, sebaran, reproduksi dan pemanfaatan makroalga marga Turbinaria. Diharapkan dengan tulisan ini dapat memberikan gambaran morfologi Turbinaria sehingga memperkecil kesalahan dalam penamaan, mengetahui habitat dan sebaran Turbinaria sehingga mempermudah untuk mencari keberadaannya di alam, mengetahui sistem reproduksi sehingga membantu proses penentuan teknik budidaya dan informasi pemanfaatan makroalga diharapkan dapat memberikan gambaran tentang pentingnya Turbinaria dalam kehidupan manusia.

\section{SISTEMATIKA}

Marga Turbinaria termasuk makroalga coklat yang semula masuk dalam filum Phaeophyta, namun setelah mengalami perubahan tata nama taksonomi, filum ini berubah menjadi Ochrophyta (Atmadja \& Prud'home van Reine, 2014). Makroalga ini secara sekilas mirip dengan Sargassum, karena berasal dari famili yang sama yaitu Sargassaceae. Kemiripan Turbinaria tidak hanya terhadap Sargassum saja tetapi juga terhadap Hormophysa, karena ketiga marga tersebut berasal dari famili yang sama yaitu Saegassaceae. Berdasarkan Guiry \& Guiry (2018), sistematika dari Turbinaria adalah sebagai berikut:

$\begin{array}{ll}\text { Filum } & : \text { Ochrophyta } \\ \text { Subfilum } & \text { : Phaeista } \\ \text { Kelas } & \text { : Phaeophyceae } \\ \text { Subkelas } & \text { : Fucophycidae } \\ \text { Ordo } & : \text { Fucales } \\ \text { Famili } & : \text { Sargassaceae } \\ \text { Genus } & : \text { Turbinaria }\end{array}$

\section{DIVERSITAS Turbinaria DI INDONESIA}

Turbinaria termasuk makroalga yang sering kita jumpai di Perairan Indonesia walaupun memiliki diversitas yang rendah. Sampai saat ini, sudah tercatat sebanyak 11 spesies Turbinaria yang ditemukan di Indonesia (Atmadja \& Prud'home van Reine, 2014) dari 35 spesies yang ditemukan di dunia (Guiry \& Guiry, 2018). Diversitas spesies Turbinaria dapat dilihat pada Tabel 1.

Tabel 1. Diversitas Spesies Turbinaria di Indonesia (Atmadja \& Prud'home van Reine, 2014).

\begin{tabular}{|l|l|l|l|}
\hline No & \multicolumn{1}{|c|}{ Nama Spesies } & No & \multicolumn{1}{c|}{ Nama Spesies } \\
\hline 1 & Turbinaria condensata & 7 & Turbinaria parvifolia \\
\hline 2 & Turbinaria conoides & 8 & Turbinaria trialata \\
\hline 3 & Turbinaria decurrens & 9 & Turbinaria tricostata \\
\hline 4 & Turbinaria luzonensis & 10 & Turbinaria turbinata \\
\hline 5 & Turbinaria murrayana & 11 & Turbinaria vulgaris \\
\hline 6 & Turbinaria ornata & & \\
\hline
\end{tabular}


Tiga dari 11 spesies Turbinaria yang ditemukan di Indonesia merupakan spesies yang umum ditemukan, yaitu $T$. conoides, $T$. decurrens, dan $T$. ornata. Sedangkan spesies Turbinaria yang lain lebih jarang ditemukan (Atmadja \& Prud'home van Reine, 2014). Berikut adalah perbedaan morfologi ketiga spesies Turbinaria yang umum ditemukan di Indonesia.

\section{a. Turbinaria conoides}

Turbinaria conoides secara umum memiliki batang silindris, tegak, kasar dan terdapat bekas-bekas percabangan, memiliki holdfast (alat menempel) berupa cakram kecil dan terdapat perakaran yang menjalar ke segala arah (radial). Spesies ini memiliki percabangan berputar sekeliling batang utama dan daun berukuran kecil (diameter sekitar satu sentimeter). Ciri spesifik dari spesies ini adalah daun yang membentuk setengah bulatan melengkung seperti ginjal (reniformis) dengan pinggir daun bergerigi. T. conoides memiliki gelembung udara yang terletak agak menonjol di pertengahan daun. Spesies ini dapat memiliki rumpun setinggi 75 cm (Atmadja, 1996). Thalus berwarna coklat muda hingga coklat tua (Mirza, 1966; Atmadja, 1996). Gelembung udara (vesicles) menempel pada daun. Organ reproduksi (receptacle) menempel pada tangkai ramuli dan membentuk rangkaian pada tangkai daun (Wei \& Chen, 1983; Atmadja, 1996).

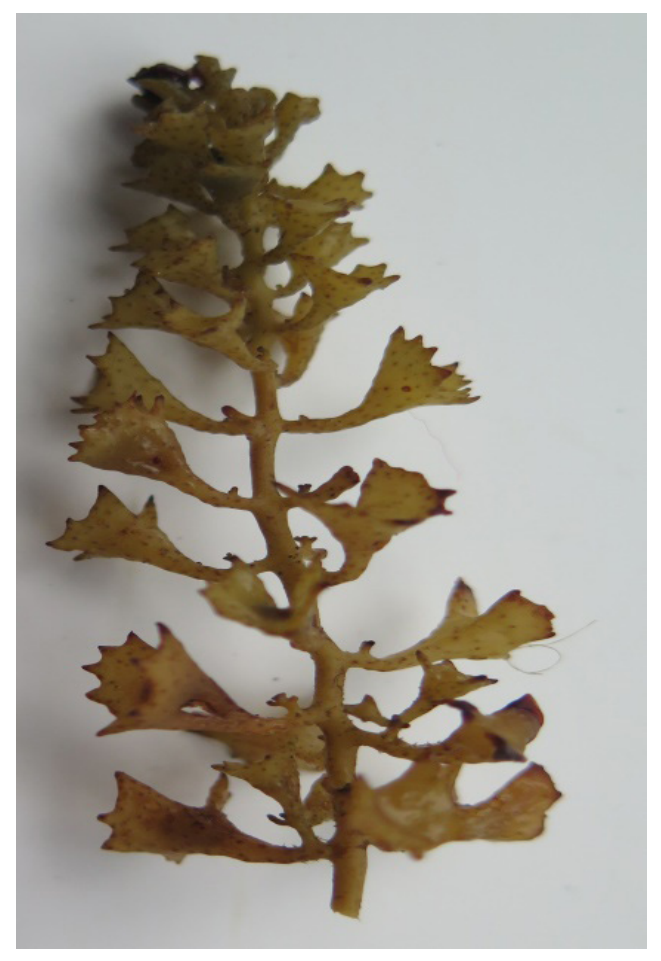

Gambar 1. Morfologi Turbinaria conoides (Foto: koleksi pribadi). 


\section{b. Turbinaria decurrens}

Turbinaria decurrens memiliki ciri umum seperti Turbinaria lainnya yaitu batang silindris, tegak, kasar dan terdapat bekas-bekas percabangan, holdfast berupa cakram kecil dengan perakaran radial dan percabangan berputar sekeliling batang utama. Spesies ini memiliki ciri spesifik berupa bentuk daun yang menyerupai kerucut segitiga (Atmadja, 1996). Gelembung udara (vesicle) berbentuk sedikit piramid. Reseptakel bergerombol membentuk racemose (Mirza, 1966).

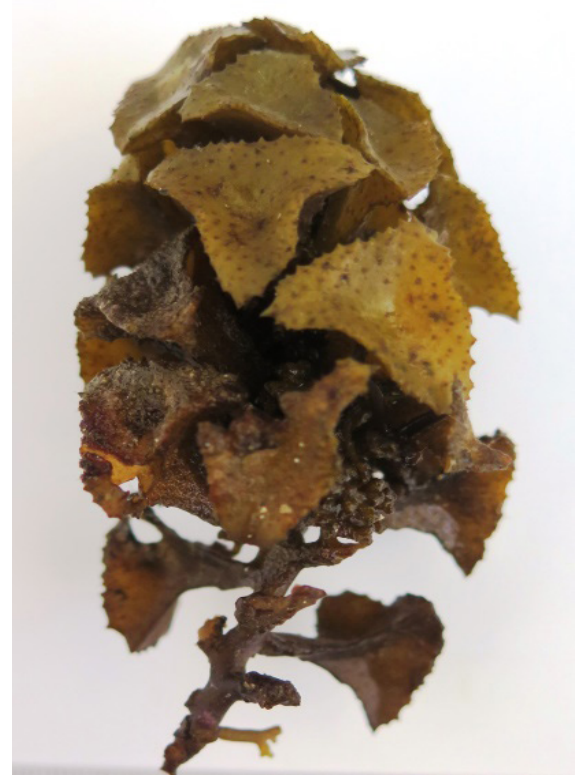

Gambar 2. Morfologi Turbinaria decurrens (Foto: koleksi pribadi).

\section{c. Turbinaria ornata}

Turbinaria ornata juga memiliki ciri umum seperti Turbinaria lainnya yaitu batang silindris, tegak, kasar dan terdapat bekas-bekas percabangan, holdfast berupa cakram kecil dengan perakaran radial dan percabangan berputar sekeliling batang utama. Perbedaan dengan jenis lainnya adalah daun yang berbentuk seperti corong dengan pinggir bergerigi. Karakteristik jenis ini adalah pinggir daun membentuk bibir dengan bagian tengah daun melengkung ke dalam (Atmadja, 1996). Ramuli atau daun tersusun secara melingkar pada batang. Lebar daun sekitar $1 \mathrm{~cm}$ dengan panjang 0,8 cm (Wei \& Chen, 1983). 


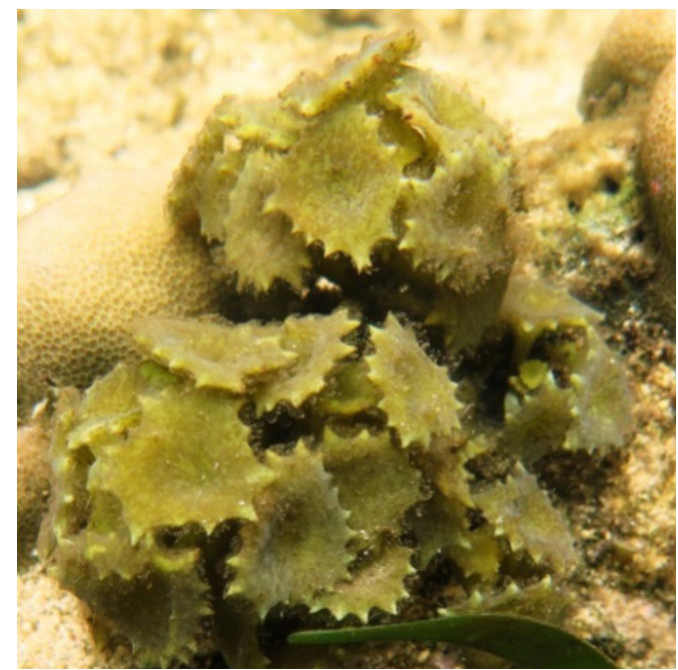

Gambar 3. Morfologi Turbinaria ornata (Foto: koleksi pribadi)

\section{HABITAT DAN DISTRIBUSI}

Turbinaria ditemukan di perairan intertidal sampai dengan subtidal. Turbinaria memiliki toleransi yang tinggi terhadap beberapa parameter lingkungan seperti kekeringan, cahaya matahari serta variasi salinitas dan temperatur. Turbinaria tumbuh di daerah intertidal berbatu, rataan terumbu dan menempel pada substrat keras seperti karang hidup, karang mati maupun batuan beku
(Magrunder \& Hunt, 1979; Atmadja, 1996). Turbinaria decurrens terdapat lebih banyak di daerah rataan terumbu bagian luar atau di tempat-tempat yang terkena ombak secara langsung. Turbinaria conoides dan $T$. ornata tumbuh di daerah rataan terumbu serta menempel pada substrat keras seperti karang mati, karang hidup maupun batuan vulkanik (Atmadja, 1996). Gambar 4 menunjukan substrat tempat tumbuh marga Turbinaria.

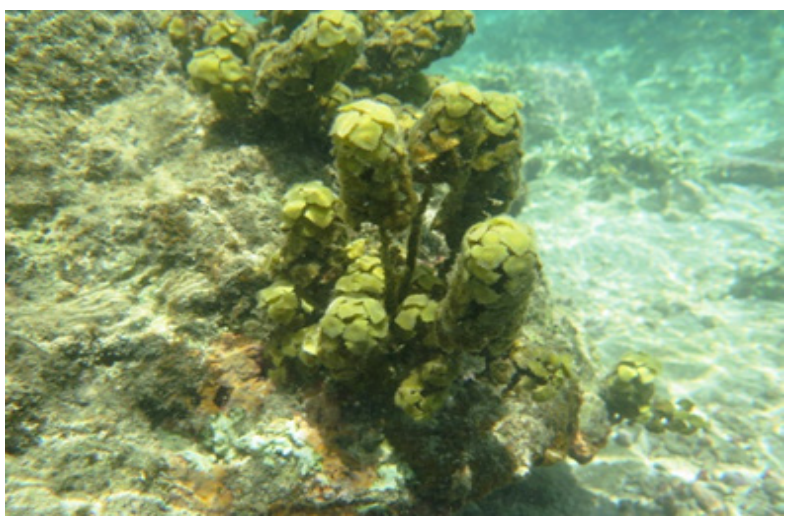

Gambar 4. Bentuk substrat dasar dimana pertumbuhan Turbinaria umum dijumpai (Foto:koleksi pribadi). 
Distribusi Turbinaria di dunia meliputi Benua antara lain: Amerika, Afrika, Asia dan Australia (Tabel 2) (Guiry \& Guiry, 2018). Turbinaria tumbuh tersebar hampir di seluruh wilayah perairan Indonesia. Wilayah yang memiliki diversitas Turbinaria tertinggi adalah Pulau Sumatera dan sekitarnya (tujuh spesies) dan selanjutnya adalah Pulau Jawa dan sekitarnya (enam spesies). Sedangkan wilayah yang memiliki diversitas Turbinaria terendah adalah Pulau Kalimantan dan sekitarnya (satu spesies) (Gambar 5). Walaupun
Pulau Sumatera dan sekitarnya memiliki diversitas spesies tertinggi, tetapi Pulau Sulawesi dan sekitarnya memiliki tingkat keseringan ditemukan Turbinaria paling tinggi yaitu 19 dari 64 lokasi. Sedangkan wilayah yang memiliki tingkat keseringan ditemukan Turbinaria paling rendah adalah Pulau Kalimantan dan sekitarnya (4 dari 64 lokasi). Turbinaria conoides, T. decurrens, T. murrayana dan T. ornata dapat ditemukan di 4-5 wilayah (Gambar 5) (Atmadja \& Prud'home van Reine, 2014).

Tabel 2. Sebaran Turbinaria di Dunia (Guiry \& Guiry, 2018).

\begin{tabular}{|l|l|l|}
\hline No & \multicolumn{1}{|c|}{ Benua } & \multicolumn{1}{c|}{ Negara/Wilayah } \\
\hline 1 & Amerika & $\begin{array}{l}\text { Chili, Amerika Serikat, American Samao, Polinesia Tengah, } \\
\text { Kepulauan Cook, Micronesia, Fiji, Guam, Kepulauan Hawaii, } \\
\text { Kepulauan Line, Kepulauan Mariana, Kepulauan Marshall, } \\
\text { New Caledonia, Kepulauan Samoan, Kepulauan Solomon, } \\
\text { Atol Wake, Pulau Wallis, dan Pulau Futuna }\end{array}$ \\
\hline 2 & Afrika & $\begin{array}{l}\text { Eritrea, Kenya, Madagaskar, Mauritus, Mozambique, } \\
\text { Somalia, Afrika Selatan, Tanzania, Kepulauan Aldabra, } \\
\text { Seychelles, }\end{array}$ \\
\hline 3 & Asia & $\begin{array}{l}\text { Indonesia, Malaysia, Myanmar, Filipina, Singapura, Thailand, } \\
\text { Vietnam, China, Japan, Korea, Laut China Selatan, Taiwan, } \\
\text { Pulau Yonaguni, Teluk Arab, India, Oman, Sri Lanka, Papua } \\
\text { New Guinea, Kepulauan Andaman, }\end{array}$ \\
\hline 4 & Australia & $\begin{array}{l}\text { Teritori Kepulauan Coral Sea, Queensland, Australia Barat, } \\
\text { Pulau Chrismas, }\end{array}$ \\
\hline
\end{tabular}




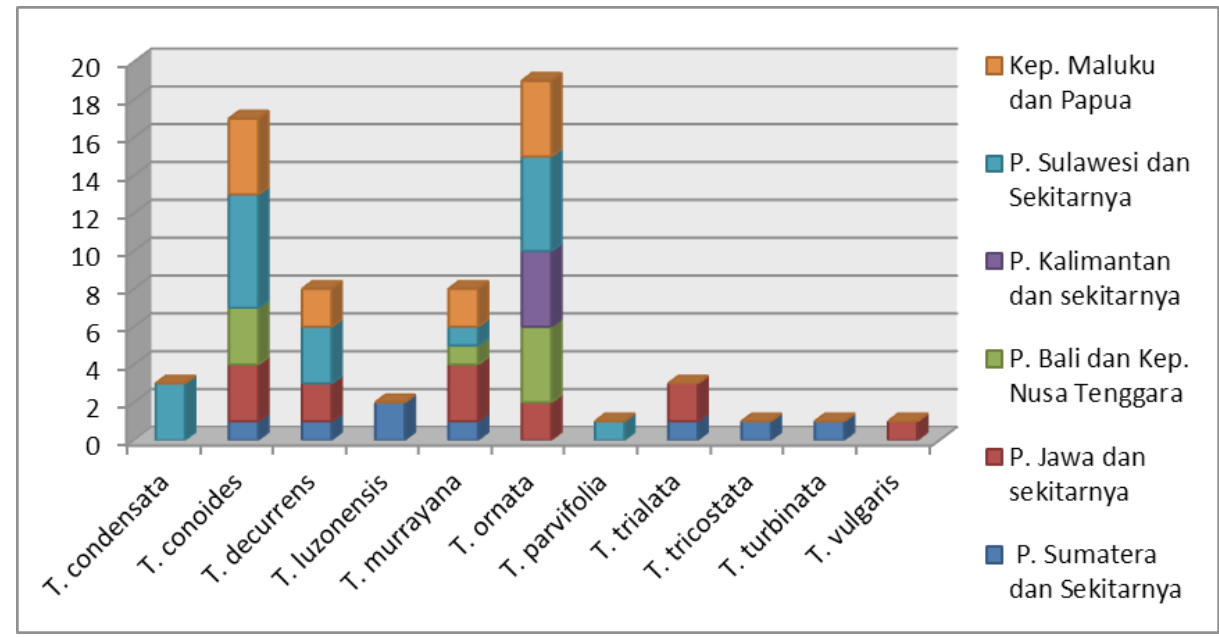

Gambar 5. Sebaran Turbinaria di Indonesia (diolah dari data Atmadja \& Prud'home van Reine, 2014).

\section{SISTEM REPRODUKSI}

Sistem reproduksi Turbinaria secara umum mengikuti pola reproduksi makroalga coklat pada umumnya, yaitu melalui pergantian generasi antara seksual dan aseksual. Makroalga ini memiliki dua fase pertumbuhan yaitu gametofit dan sporofit. Thalus multiselulernya bersifat diploid sedangkan gamet bersifat haploid (Atmadja \& Prud'home van Reine, 2014).
Fase pertumbuhan Turbinaria (makroalga coklat) sama dengan makroalga hijau, yaitu memiliki dua fase pertumbuhan (gametofit dan sprorofit). Berbeda dengan makroalga merah yang memiliki tiga fase pertumbuhan, yaitu gametofit, karposporofit dan tetrasporofit (Atmadja \& Prud'home van Reine, 2010; Atmadja $\&$ Prud'home van Reine, 2014). Siklus reproduksi Turbinaria dapat dilihat pada Gambar 6.

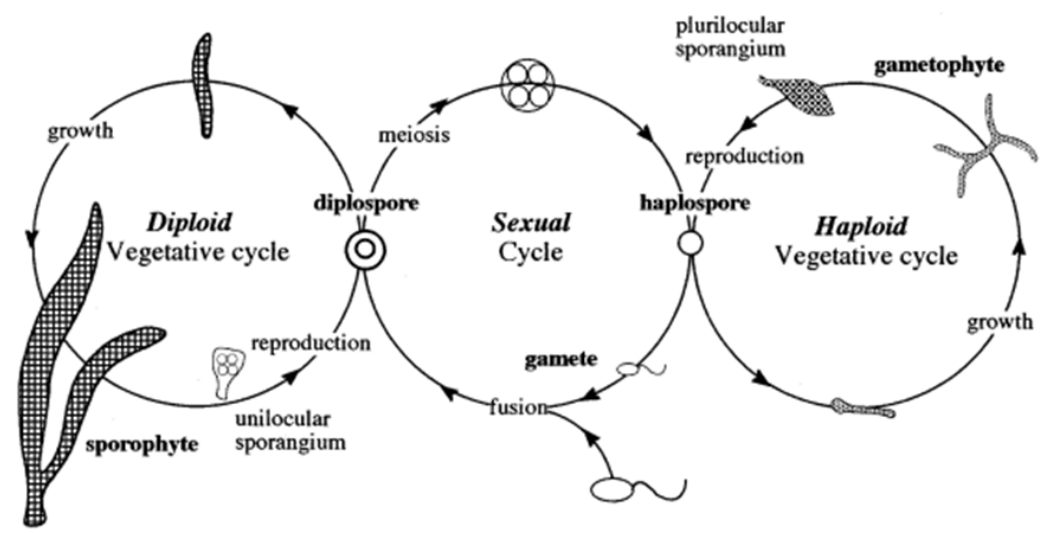

Gambar 6. Siklus reproduksi Turbinaria (Fucales) yang terjadi melalui pergantian antara seksual dan aseksual/vegetatif (Bell, 1997). 
Tahap reproduksi seksual, gametofit menghasilkan sprorofit melalui pertumbuhan zigot. Sedangkan reproduksi aseksual, gametofit atau sporofit dihasilkan dari sporofit melalui perkembangan zoospora. Gametofit umumnya membentuk gametofit kembali, sedangkan sporofit membentuk menjadi sporofit kembali atau melalui meiosis membentuk gametofit. Spora dan gamet dilengkapi dengan flagella (zoospora dan zoogamet), tetapi gametgamet betina yang memiliki ovum dalam oogoniumnya tidak bergerak (Atmadja \& Prud'home van Reine, 2014).

\section{PEMANFAATAN}

Turbinaria merupakan salah satu makroalga yang memiliki nilai ekonomi, walaupun bukan merupakan produk unggulan rumput laut. Selain dimanfaatkan sebagai sumber alginat, Turbinaria juga dimanfaatkan dalam bidang industri farmasi. Berikut adalah pemanfaatan dari Turbinaria:

a. Sumber alginat

Pada dasarnya, semua makroalga coklat mengandung alginat, hanya saja setiap spesies makroalga memiliki rendemen dan kualitas alginat yang berbeda-beda. Begitu juga dengan Turbinaria yang merupakan penghasil alginat. Alginat merupakan komponen penting penyusun dinding sel makroalga coklat. Alginat secara umum memiliki dua bentuk yaitu asam dan garam. Bentuk asam dari alginat biasa disebut dengan asam alginat, sedangkan bentuk garamnya biasa disebut sebagai natrium alginat (Rasyid, 2003).

Kandungan alginat pada Turbinaria dapat mencapai 25-56\% dari berat keringnya (Rasmussen \& Morrissey, 2007; Laksanawati et al., 2017; Kusumawati et al., 2018). Alginat dimanfaatkan dalam berbagai industri seperti industri makanan, pakan, kosmetik maupun farmasi (Murata \& Nakazoe, 2001). Alginat memiliki aktivitas antihipertensi, antik anker, antiobesitas, antikolesterol, dan antidiabetes (Kimura et al. 1996; Murata \& Nakazoe, 2001; Holdt \& Kraan, 2011).

\section{b. Sumber Fukoidan}

Fukoidan umumnya ditemukan pada makroalga coklat termasuk Turbinaria. Senyawa ini tidak dapat ditemukan pada makroalga lain maupun tumbuhan tingkat tinggi. Fukoidan memiliki bioaktivitas bagi kesehatan manusia, antara lain aktivitas antikoagulan (Chevolot et al., 1999), antivirus (Li et al., 1995; Iqbal et al., 2000), antioksidan (Hu et al., 2001), antitumor (Maruyama et al., 2006; Verdrengh et al., 2000) dan antikanker (Liu et al., 2005). Fukoidan juga mendorong pemulihan fungsi kekebalan tubuh (Wu et al., 2003).

c. Sumber iodin

Turbinaria merupakan salah satu makroalga coklat penghasil iodin (Atmadja, 1996; Ode \& Wasahua, 
2014). Iodin dimanfaatkan sebagai antiseptik, mencegah penyakit gondok, pengujian amilum di laboratorium, fotografi (Anonim, 2018) dan suplemen untuk ibu hamil (Lazarus, 2015).

d. Sumber polisakarida bioaktif lainnya Makroalga merupakan sumber polisakarida bioaktif dari laut (Holdt \& Kraan, 2011). Senyawa polifenil dari $T$. ornata memiliki aktivitas antioksidan (Vijayabaskar \& Shiyamala, 2012; ). Ekstrak heksan dari $T$. ornata memiliki aktivitas antioksidan dan antiploriferasi (Deepak, et al., 2017). Turbinaria conoides memiliki aktivitas antibakteri, antioksidan dan antikanker (Ponnan et al., 2017), sedangkan $T$. decurrens memiliki aktivitas antikanker (Zakaria et al., 2018).

\section{PENUTUP}

Indonesia memiliki kekayaan spesies Turbinaria sebanyak 11 spesies. Jumlah spesies tersebut dapat mengalami perubahan seiring dengan perkembangan tata nama ilmiah, ditemukannya spesies atau temuan baru dan hilangnya spesies karena faktor antropogenik dan faktor bencana alam. Penelitian Turbinaria lebih banyak berkembang pada penelitian pemanfaatan dibandingkan dengan penelitian taksonomi dan budidaya. Penelitian pemanfaatan Turbinaria dalam bidang farmasi seperti sebagai antioksidan, antikanker, antibakteri, antikoagulan, antiploriferasi dan antivirus. Pemanfaatan Turbinaria dalam bidang farmasi sebagian sudah dalam tahap percobaan pada manusia, namun demikian masih ada yang dalam tahap percobaan pada mamalia lain (mencit/ tikus percobaan). Penelitian lebih lanjut terhadap pemanfaatan Turbinaria dalam bidang farmasi masih terus dikembangkan sampai saat ini. Penelitian dalam bidang taksonomi dan budidaya perlu dikembangkan untuk menunjang penyediaan stok Turbinaria dalam industri farmasi.

\section{DAFTAR PUSTAKA}

Anonim. 2018. Iodin. http://id.wikipedia. org. Diakses pada Tanggal 19 November 2018.

Atmadja, W. S. 1996. Pengenalan jenis algae coklat (Phaeophyta). Dalam: Atmadja, W.S., A. Kadi, Sulistijo dan Rachmaniar (Eds). Pengenalan Jenis-Jenis Rumput Laut Indonesia. Pusat Penelitian dan Pengembangan Oseanologi-LIPI, Jakarta. 191 hal.

Atmadja, W. S. and W. F. Prud'home van reine. 2010. Checklist of the Seaweed Species Biodiversity of Indonesia with Distribution and Classification: Red Algae (Rhodophyceae). Natural Biodiversity Center and Indonesian Institute of Sciencies (LIPI), Jakarta. 72 pp. 
Atmadja, W. S. and W. F. Prud'homme van reine. 2014. Checklist of the Seaweed Species Biodiversity of Indonesia with Distribution and Classification: Green Algae (Chlorophyta) and Brown Algae (Phaeophyceae, Ochrophyta). Natural Biodiversity Center and Indonesian Institute of Sciencies (LIPI), Jakarta. 59 pp.

Bell G. 1997. The Evolution of the life cycle of brown seaweeds. Biological Journal of the Linnean Society, 60: 21-38.

Chevolot L, A. Foucault, F. Chaubet, N. Kervarec, C. Sinquin, A. M. Fisher A. M, and C. Boisson-Vidal. 1999. Further data on the structure of brown seaweed fucans: relationships with anticoagulant activity. Carbohydr. Res. 319:154-165.

Deepak P., R. Sowmiya, G. Balasubramani and P. Perumal. 2017. Phytochemical prolifing of Turbinaria ornata and its antioxidant and antiproliferative effects. Journal of Taibah University Medical Sciences. 12 (4): 329-337.

Guiry, M. D. and Guiry, G. M. 2018. AlgaeBase. World-wide electronic publication, National University of Ireland, Galway (taxonomic information republished from AlgaeBase with permission of M.D. Guiry). Turbinaria J.V. Lamouroux,
1825.

Handayani, T. 2014. Rumput laut sebagai sumber polisakarida bioaktif. Oseana 39 (2): 1-11.

Holdt S.L. and S. Kraan. 2011. Bioactive compounds in seaweed: functional food applications and legislation. J. Appl. Phycol 23: 543-597.

$\mathrm{Hu}$ J. F, M. Y. Geng, J. T. Zhang, and H.D. Jiang. 2001. An in vitro study of the structure-activity relationships of sulfated polysaccharide from brown algae to its antioxidant effect. J. Asian Nat. Prod. Res. 3:353358.

Iqbal M, H. Flick-Smith, and J.W. McCauley. 2000. Interactions of bovine viral diarrhoea virus glycoprotein E-rns with cell surface glycosaminoglycans. $J$. Gen. Virol. 81:451-459.

Kimura Y, K. Watanabe, and H. Okuda. 1996. Effects of soluble sodium alginate on cholesterol excretion and glucose tolerance in rats. J. Ethnopharmacol 54:47-54.

Kusumawati R., B. Jamal and S. B. U. Bagus. 201. Characteristics of SodiumAlginate Extracted from Turbinaria sp. and Sargassum sp. Squalen Bulletin of Marine and Fisheries Postharvest and Biotechnology. 13 (79). DOI: 10.15578/squalen.v13i2.297. 
Laksanawati R., Ustadii dan H. Amir. 2017. Pengembangan metode ekstraksi alginat dari rumput laut Turbinaria ornata. Jurnal Pengolahan Hasil Perikanan Indonesia. 20 (2): . 362-369.

Lazarus, J. H. 2015. The importance of iodine in public health. Environmental Geochemistry and Health. 37 (4). Doi:10.1007/ s10653-015-9681-4.

Li F, T.C. Tian, and Y.C. Shi. 1995. Study on anti virus effect of fucoidan in vitro. J. Norman Bethune Univ. Med. Sci. 21:255-257.

Liu R.M, J. Bignon, F. Haroun-Bouhedja, P. Bittoun, J. Vassy, S. Fermandjian, J. WdzieczakBakala, and C. BoissonVidal. 2005. Inhibitory effect of fucoidan on the adhesion of adenocarcinoma cells to fibronectin. Anticancer Res. 25:2129-2133.

Magrunder W. H. and J. W. Hunt. 1979. Seaweeds of Hawaii. Oriental Publising Company. 116 pp.

Mirza J. N. 1966. Phaeophyceae in India. Indian Council of Agricultural Research, New Delhi. 202 pp.

Murata M, and J. Nakazoe. 2001. Production and use of marine algae in Japan. Jpn. Agr. Res. Q. 35:281-290.

Maruyama H, H. Tamauchi, M. Iizuka, and T. Nakano. 2006. The role of NK cells in antitumor activity of dietary fucoidan from Undoria pinnotifida sporophylls (Mekabu). Planta Med. 72:1415-1417.

Ode I. dan J. Wasahua. 2014. Jenisjenis alga coklat potensial di perairan Pantai Desa Hutumuri Pulau Ambon. Jurnal Ilmiah Agribisnis dan Perikanan. 7 (2): 39-45.

Ponnan A., K. Ramu, M. Marudhamuthu, R. Marimuthu, K. Siva and M. Kadarkarai. 2017. Antibacterial, antioxidant and anticancer properties of Turbinaria conoides (J. Agaradh) Kuetz. Clinical Phytoscience, 5 (3):110. DOI 10.1186/s40816-0170042-y

Rasmussen R.S, and M.T. Morrissey. 2007. Marine biotechnology for production of food ingredients. Advances in food and nutrition research, 52: 237-292.

Rasyid A. 2003. Algae coklat (Phaeophyta) sebagai sumber alginat. Oseana, 28 (1): 33-38.

Verdrengh M, H. Erlandsson-Harris, and A. Tarkowski. 2000. Role of selectins in experimental Staphylococcus aureus-induced arthritis. Eur. J. Immunol. 30:1606-1613.

Vijayabaskar P. and V. Shiyamala. 2012. Antioxidant properties of seaweed polyphenol from Turbinaria ornata (Turner) J. Agardh, 1948. Asian Pacific Journal of Tropical Biomedicine. S90-S98. 
Wei T. L. and W. Y. Chen. 1983. Seaweeds of Singapure. Singapure University Press, National University of Singapure. 123 pp.

Wu X.W, M.L. Yang, X.L. Huang, J. Yan, and Q. Luo. 2003. Effect of fucoidan on splenic lymphocyte apoptosis induced by radiation. Chin. J. Radiol. Med. Prot. 23:43-50.
Zakaria A. D., K. Basah and A. Bahtiar. 2018. Cytotoxic activity of extract and active fraction of Turbinaria decurrens bory oncolon cancer cell line HCT116. Int. J. Morphol. 36(3):979983. 